\title{
アルミ合金ボールジョイントを用いた単位単層ラチスドームの 載荷試験と弾塑性解析 \\ EXPERIMENTS AND ANALYSES OF UNIT SINGLE LAYERED RETICULAR DOMES USING ALUMINUM BALL JOINTS FOR THE CONNECTION
}

\author{
桧山 裕二郎*, 高 島 英 幸**, 飯島 俊比古*** \\ Yujiro HIYAMA, Hideyuki TAKASHIMA and Toshihiko IIJIMA
}

\begin{abstract}
An aluminum single layered reticular dome is expected to be a suitable construction system for large span dome structures, because of characteristics such as a high strength and stiflness to weight ratio. Regarding the aluminum ball joints of single layered reticular domes, the authors have researched the bending stiffness and strength through structural testing and numerical simulation as discussed in a previous paper. As a result, this type of connection, with semi-rigidity, was confirmed to perform stable hysteresis.

This study deals with the structural behavior of the unit reticular dome, making use of aluminum ball joints. In order to clarify the buckling behavior of such a unit dome, structural testing and analyses are executed with varied parameters; the subtended half angle and the slenderness ratio. Through these structural tests and analyses, a yielding interaction formula for such aluminum ball joints is obtained, and further an effective coefficient for the bending stiffness of the connection is found in order to simulate the actual behaviors of such unit domes.
\end{abstract}

Keywords: single layered reticular dome, ball joint connection, ahuminum alloy; buckling behavior, loading test, nonlinear analysis 単層ラチスドーム, ボールジョイント,アルミ合金, 座屈举動, 載荷試娩, 非線形解析

\section{1.はじめに}

アルミ合金製の単層ラチスドームは,アルミが比重に対して㴊性 や耐力が高いことから,大スパンの架構に適することが予想される。 一方, アルミ合金は剛性が鋼材の約 $1 / 3$ と構造としての変形が大 きいが，単層ラチスドームが荷重を面内力で負担寸ることから際立 った欠点とはならない。しかしながら，アルミ合金は一般に材料の 降伏比が高く降伏後の耐力上昇が見込めないことから，単層ラチス ドームとして用いる場合, ドームの変形と応力状態考慮した座屈 耐力の正しい評洒が必要となる。

著者らは文献[1]において，このアルミ合金製単層ラチスドーム に用いるねじ込み式ボールジョイントに関して, その曲げ用性と耐 力を構造実験と数值解析により分析した。単層ラチスドームの外力 に対する幾何非線形性と座屈举動は, 接合部の曲代㓮性上耐力に大 きく左右される。たとえば加藤15１8）は，ドームの座屈藏重推 定法としてその無次元表示である $\eta-\xi$ 関係の中で，また，山四 ${ }^{1}$ 4) は同様にドームの座屈荷重の無次元表示である $\alpha-S$ 関孫主用 い,ドームの座屈举動が接合部の曲げ剛性に強く影響されることを 解析的に示している。そこで文献[1 ]では，当該接合部に関して， まず軸力がない場合の接合部の曲げ性能を構造実験により明らか にした。文献[1]で対象としたねじ込み式ボールジョイントは，接 合部が曲げに対して離間するため，その特性をシミュレートするた

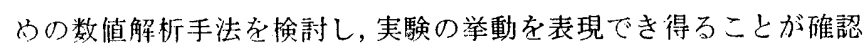
でた。さらに，曲计用性と耐力长算定する近以式至提案し，実駼 值との比較友踏まえ, その力学特性在ほぼ把握できた。つまり, こ の斗剛接合的な特性充持つ当該接合部は，曲げ降伏に上万脆性的な 破壊はなく，そゆ曲代举動恃比較的安定した復元力特性在有してい ろこと，また接合部龙搆成寸るカラー(図 1 )の断面圭上げることに より曲计剛性と耐力の上昇が期待できることが確認できた。その結 果，当該接合部は，トラス部材に対して曲䟝性老比較的高く設定 できるため，単層ラチスドームの接合部として有效であううことが 予想されろ。

本研究の背景に関わる研究袭列举しておく。トラス節点に用い

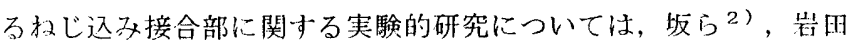

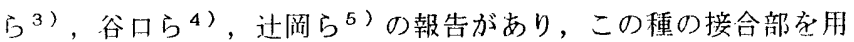
いた単層ラチスドームの載荷試験に基づく座屈耐力については, 斎 藤ら ${ }^{6)}$, 植木ら 7.8$)$ 等で議論されている。また, 鉿木ら ${ }^{9)}$, 山

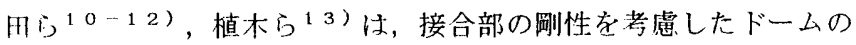
座扈耐力の分析を進的た。さらに,ドームの座屈荷重の推定法とし

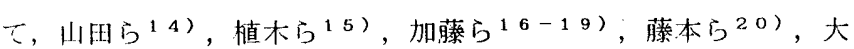
沢ら 2.11$)$ の提案がある。接合部の回転座屈については, 半谷ら 22 . 2.3)の破究もある。本研究でも用いたねじ込多接合部の数值解析手 法については，高島ら24，25）の研究がある。一方，アルミ合金
* 住友軽金属厂業・設計技術部

** 関東学:院大学工学部建築学科 助教授・ 一博

*** 饭島建筑事務所 工博
Sumitomo Light Metal Industries, Ltd

Assoc. Prof., Dept. of Architecture, Faculty of Eng., Kanto Gakuin Univ., Dr. Eng. Iijima Structural Design Office, Dr. Eng. 
については，は合合い接合有用いた単層ラチスドームに関手る杉崎

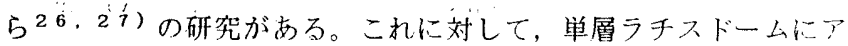
ルミ合金製のねじ込み式ボールジョイント文用い，その座屈举動 構造実験と数值解析から分析した例はない。

そこで本研究では，文献[1]に引き続き，この接合部友用いた単 層ラチスドームに関してトドムの座屈举動に大きく影留子る接合 部の㓮性と耐力に関寸る設計的知見左得万ため, 以下の研究在進的 る。1)・゙ームの最小単位である単位ラチスドーム在対象に，部材 半開角, 部材細長比龙実験変数亡した載荷試験在実施し, その崩壊 形式在確認寸る。次に，2）実験結果から，単位ドームの忘力・変 形特性を調べるとともに，3）軸力と曲げモーメントがある場合の

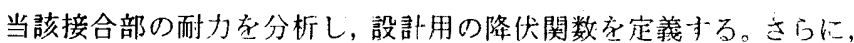
4 ）実験モデルに対して材料および幽何非線形解析在実施し，実験 結果と比較して数値解析の適用性圭明ら加に寸る。注11

\section{2. 载荷試殹}

当該接合部在用いた単層ラチスドームに関して，その耐力と座 屈举動, および軸力と曲げモーメントが導入された接合部の力学特 性を調べる目的で, 実大の単位単層ラチスドームの骨組試験体在用 い, 静的な載荷試験索実施した。

\section{1 供試体}

載荷試験に用いた接合部は文献[1]で対象としたアルミ合金初じ 込み式ボールジョイントと同じ形状，機權である。接合部の形状上 使用材料およびその規格索図 1 に示寸。ストラットと称寺るトラス 材は，中空円形管の材端にエンドプラグと称寸る金物龙溶接して製 作される。ストラットには高力ボルトがあらかじあ挿入されており， またこの高力ボルトは断面方向にピンが打ち込まれており，このピ ンがパイプ形状のカラーの浶に納まっている。このカラーを回転さ せ締め込むこととより高力ボルトはハブと称子万中実球形体の接 合金具にねじ込まれ，ストラットとハブが接合される。

ハブとエンドプラグは，アルミ合金押出し棒在切削加エして，所 定の形状に製作される。ストラットレカラーはアルミ合金押仙し材 をそのまま用いている。アルミ合金部材は全て A N - Zn-Si 系熱処理合 金 A6061であり，高力ボルトはF8T 相当のクロムーモリブテン銅 の焼き入れ材である。アルミ合金部材の材料特性については文献 [1]に詳述されているのでここではその説明在割愛寸る。
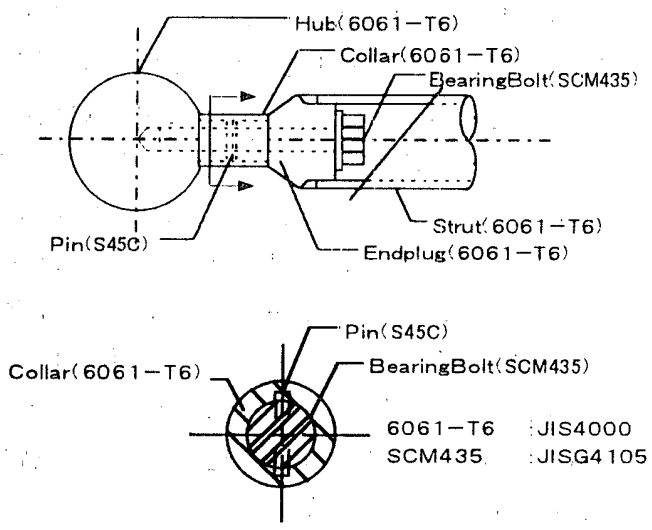

図 1 接合部 $の$ 形状と使用材料
载荷試験に用いた 6 種類の供試体の構成部材主表 1 亿，满成材

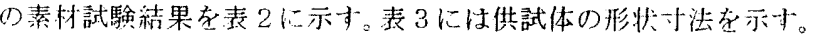

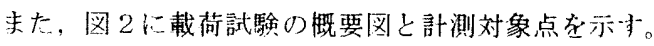

表1に扔いて，搆成部材の組夕合わせは 2 種類でる。U 1 か

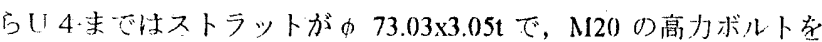

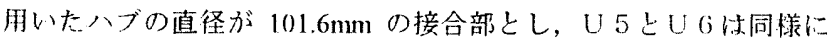
の 101.6x5.74t と M33 扩よび八ブ径 $\phi 139.7$ の組々合わせである。 それぞれのカラーの径はボルトの径の 2 倍である。ボルトの引悙酎

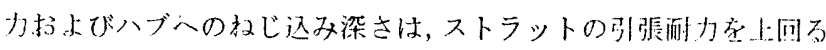
よう設定されている。

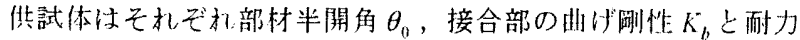
$M_{y}$, 部材細長比 $\lambda_{s}$ の異なる正六角形平面の巣位うチスドームだ ある。表 3 に扔いて，部材半開角 $\theta_{0}$ は鋼材による的層ラチスドー

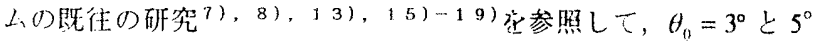
在採用した。つまり， $\theta_{0}=3^{\circ}$ は接合部の㓮性がドームの節点座层

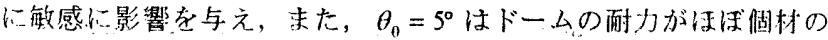
座属亡全体座屈で決定される。表 4 に各武供体のストラットの断通 性能及び細長比 $\lambda_{s}$ ，接合部の曲代剛性 $K_{b}$ と降伏曲计でーメント $M_{y}$ ，力ラーの压采有効断面積, $A_{e}$, ストラット材の曲计用性 $E I / l_{0}$ 、陈した無次元化バ市定数 $\kappa$ 孝示寸。表中の細長比 $\lambda_{s}$ は節点 間农座屌長さとして計算している。また $\lambda_{s}$ をアルミ合金の限界細 長比 $A=80\left(\Lambda=\sqrt{\pi^{2} E / 0.5 \sigma_{y}}{ }^{3} 3\right) ）$ で無次元化した值は，0.73 から 1.00である。 $K_{b}$ こ $M_{y}$ 扔よび $A_{e}$ は文献[1]で赛施した単榇梁によ る情げ訆験で得られた值で古る。

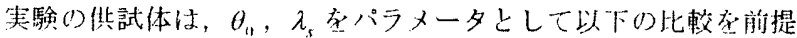
としたいる。つまり，部材半開角 $\theta_{0}$ については，供試体U 1 上U

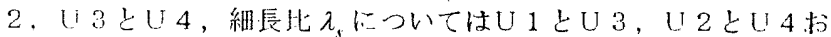
よびU上U6で古为。6体の供試体性，ストラット七接合部の組 马合わ止や部材の長さ，部材半開角 $\theta_{0}$ が，単層ラチスドームの聩 造として実現可能と予想されるものとし，特に極湍な組子合わせは 除外している。

供試佐の組々立ては，来外周のストラット6本孝ハブに数じ 込子，次に，接合部に面外の曲げが入らないよう，刘角線上の2本 のストラットを 3 対について順次ねじ込み組み立てた。

\section{表 1 。偕試体の構成部材}

\begin{tabular}{|c|c|c|c|c|}
\hline Code & $\begin{array}{l}\text { Strut } \\
(\mathrm{mm})\end{array}$ & $\begin{array}{c}\text { Bolt } \\
(\mathrm{nim})\end{array}$ & $\begin{array}{l}\text { Collar } \\
(\mathrm{mm})\end{array}$ & $\begin{array}{l}H u b \\
(\mathrm{~mm})\end{array}$ \\
\hline [1] & $\phi 7303 \times 305$ & $\mathrm{M} 20$ & $\phi 40$ & $\phi 101.6$ \\
\hline 12 & $\phi 73.03 \times 305$ & M20 & $\phi 4)$ & o 101.6 \\
\hline U3 & 6) $73.113 \times 3.05$ & $\mathrm{M} 20$ & $\phi 40$ & 101.6 \\
\hline $\mathrm{U} 4$ & $\phi 73,13 \times 3.15$ & M20 & 040 & 6101.6 \\
\hline 45 & $\phi 101(x) \times 5.74$ & M33 & $\phi 66$ & o 139.7 \\
\hline $\mathrm{U} 6$ & $\phi 101.60 \times 5.74$ & $M 33$ & $\phi 66$ & $\phi 139.7$ \\
\hline
\end{tabular}

注 1) 单層ジスドームの既往の研究では，その举動の分析に関して，多

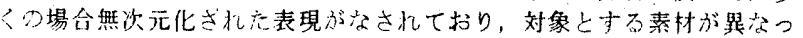

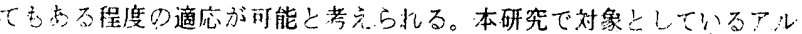

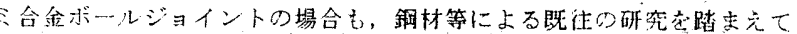

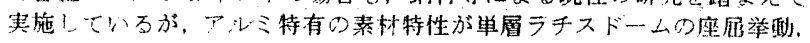
さらに振動性状に少㐫からず影響を与えることが予想されるだ，本研 究は搏造実騷による模証を前提に進めている。アルミ合金ボールジョイ ント桑用いた単層ラヂスドームに関して、健全な槽造設計在行らために

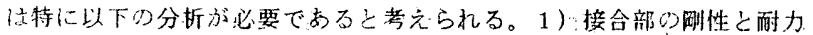

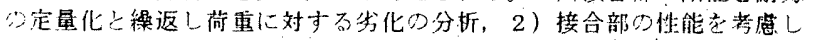

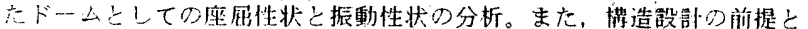

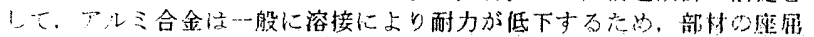

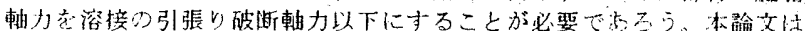

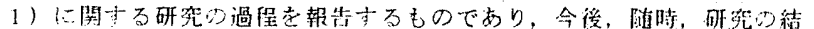

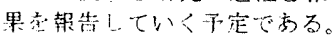


表 2. 構成部品の機械的性質

\begin{tabular}{|c|c|c|c|c|}
\hline Component & $\begin{array}{l}\text { Shape } \\
(m m)\end{array}$ & $\begin{array}{c}\text { Yield Stress } \\
\sigma_{y} \\
\left(\mathrm{kgf}^{\prime} \mathrm{cm}^{2}\right)\end{array}$ & $\begin{array}{c}\text { Tensile Strength } \\
\sigma_{u} \\
\left(\mathrm{~kg}^{\prime} \mathrm{cm}^{2}\right) \\
\end{array}$ & $\begin{array}{c}\text { Elongation } \\
(\%)\end{array}$ \\
\hline Strut & $\begin{array}{l}\phi 73.03 \times 3.05 \\
\phi 101.60 \times 5.7\end{array}$ & $\begin{array}{l}27.5 \\
27.2 \\
\end{array}$ & $\begin{array}{l}30.5 \\
29.7\end{array}$ & $\begin{array}{l}15 \\
17\end{array}$ \\
\hline Bolt & $\begin{array}{l}\text { N120 } \\
\text { M133 }\end{array}$ & $\begin{array}{l}84.6 \\
89.8\end{array}$ & $\begin{array}{l}94.1 \\
105.6\end{array}$ & - \\
\hline Collar & $\begin{array}{l}\phi 40 \\
\phi 66\end{array}$ & $\begin{array}{l}27.9 \\
29.0\end{array}$ & $\begin{array}{l}31.4 \\
32.3\end{array}$ & $\begin{array}{l}17 \\
19\end{array}$ \\
\hline Hub, End-Plug & - & 27.6 & 36.7 & 15 \\
\hline
\end{tabular}

表 3. 供武体の形状

\begin{tabular}{c|c|c|c|c|c||c|c|c}
\hline Code & $\begin{array}{c}L \\
(\mathrm{~mm})\end{array}$ & $\begin{array}{c}D \\
(\mathrm{~mm})\end{array}$ & $\begin{array}{c}\ell_{0} \\
(\mathrm{~mm})\end{array}$ & $\theta_{0}$ & $\begin{array}{c}H \\
(\mathrm{~mm})\end{array}$ & $\begin{array}{c}H^{\prime} \\
(\mathrm{mm})\end{array}$ & $h^{\prime} i$ & $h t^{\prime}$ \\
\hline \hline U1 & 1997 & 1700 & 2000 & $3^{\circ}$ & 104.7 & 105.5 & 0.032 & 0.010 \\
U2 & 1992 & 1700 & 2000 & $5^{\circ}$ & 174.3 & 172.5 & -0.073 & -0.023 \\
U3 & 1498 & 1200 & 1500 & $3^{\circ}$ & 78.5 & 77.0 & -0.060 & -0.019 \\
U4 & 1494 & 1200 & 1500 & 5 & 130.7 & 133.0 & 0.093 & 0.029 \\
U5 & 1992 & 1700 & 2000 & $5^{\circ}$ & 174.3 & 175.5 & 0.035 & 0.011 \\
U6 & 2740 & 2300 & 2750 & $5^{\circ}$ & 239.7 & 240.0 & 0.009 & 0.003 \\
\hline
\end{tabular}

表4. ストラットの断面性能と接合部の性能

\begin{tabular}{c|c|c|c|c||c|c|c||c}
\hline Code & $\begin{array}{c}A \\
\left(\mathrm{~cm}^{2}\right)\end{array}$ & $\begin{array}{c}I \\
\left(\mathrm{~cm}^{4}\right)\end{array}$ & $\lambda s$ & $\lambda s A$ & $\begin{array}{c}K_{b} \\
(t \cdot \cdot \mathrm{cm} / \mathrm{rad}\end{array}$ & $\begin{array}{c}M_{y} \\
\left(\mathrm{t} \cdot \mathrm{cm}^{\prime}\right)\end{array}$ & $\begin{array}{c}\mathrm{A}_{e} \\
\left(\mathrm{~cm}^{2}\right)\end{array}$ & $\kappa$ \\
\hline \hline U1 & 6.71 & 41.12 & 80.76 & 1.00 & 478.5 & 16.54 & 2.27 & 3.325 \\
U2 & 6.71 & 41.12 & 80.76 & 1.00 & 478.5 & 16.54 & 2.27 & 3.325 \\
U3 & 6.71 & 41.12 & 60.57 & 0.75 & 478.5 & 16.54 & 2.27 & 2.493 \\
U4 & 6.71 & 41.12 & 60.57 & 0.75 & 478.5 & 16.54 & 2.27 & 2.493 \\
U5 & 17.29 & 199.27 & 58.91 & 0.73 & 2250.0 & 76.43 & 6.67 & 3.226 \\
U6 & 17.29 & 199.27 & 81.00 & 1.00 & 2250.0 & 76.43 & 6.67 & 4.436 \\
\hline
\end{tabular}
$\left(K_{b}, M_{y}, A_{e}\right.$ は文献[1]の結果で南る)
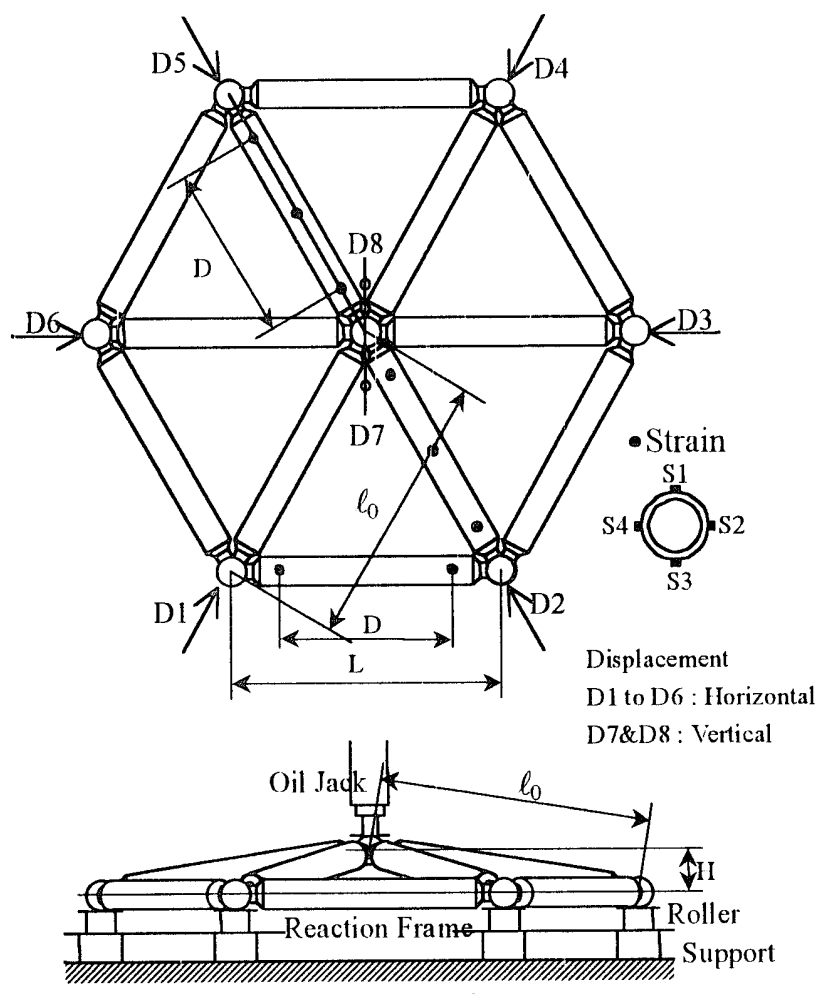

Test Bet

図2.単位ラチスドームの载荷武験

\section{2 ２２試験方法}

供試体の支持点の境界条件は，曲げの発生の最も大きくなる丑 而内口ーラ支持採用した。図 2 に扔いて，6点の支持点は，2枚 の鋼板の間に直径 $7 \mathrm{~mm}$ の鋼球を入れた支持金具を介して支持フレ 一ム上に設置した。供試体は，カラーの締め付けトルク在一律に $300 \mathrm{kgf-cm}$ としている。

荷重はテストベット上に架設された反カフレームから，20tonf オイルジャッキを佣いて中央部のハブに鉛直下向きに加えた。荷重 の值はハブとオイルジャッキ間に取り付けたロードセルにより検 出している。載荷は，U1 からU 5 は，弾性域で数回繰り返した後， 引き続き最大荷重が得られるまで単調に加力した。U６につては， 弾性域の繰り返しに加えて, 降伏荷重と推定される荷重と最大耐力 近傍でそれぞれ除荷龙絽り返した。

変位の計測は，支持点のハブについて水平，放射方向に 6 点之 加力点の八ブの直下とした。加力点については，供試体の降伏から 最大醐力に至る仮定で八ブの面内外への回転・移動主考慮し，ハブ の阔側の対象位置 2 点で計測している。

ひ多女は対角線上(稜線上)の 2 本のストラットと引㖘材となる 外周のストラットの内の一本について計測した。ひずタゲージは， 稜線上のストラットについては, 部材座屈時にヒンジの形成が予想 される部材中央部とエンドブラグとの溶接部近傍の, 合計 6 箇所に, それそ独断面周の4筒所貼り付けた。それぞれのカラーについては 中央部に断涌周の 4 䇢所貼り村けている。また，外周のストラット については，エンドプラグとの溶接部の近傍 2 筒所に, 断面周の 4 倜所貼り付计ている。

\section{2 . 3 実験結果扔よび考察}

実駼に先立ち，供試体の組立て後のライズを計测した。表 るに

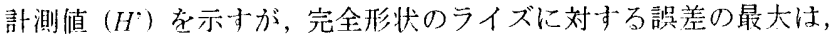
ストラットの断面二次半径に対して約 $10 \%$ であり，才问は上向き 下向き雨方向に認的られた。この誤差は，連続体シェルとしての等 洒板厚 $t_{e}$ 注 2$)$ に対しては僅か $0.03 t_{e}$ であり，実験結果の分析に際 して完全形状のライズを用いることで差し支えないと判断される。

図 3 にU 1 とU 2 について, 実験から得られた荷重・変形曲線 の処女載荷から線玥範囲内の荷重での部材軸力と曲げもーメント

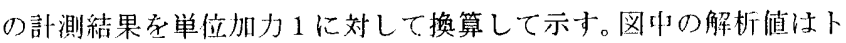
ラス材の両端を弾性の曲げバネとし，接合部をハブの直径の長さを 持つ剛域とした，線材モデルによる線形計算の結果である。ここで， 曲げばねの剛性は，表 4 に示寸文献[1]の結果を用いている。実験 值は解析值に対して，軸力は最大 1.15 倍である。曲げモーメント はモードに関してはほほ符合しているものの，頂点し材端て 25〜 $50 \%$ ，部材中間部で $20 \sim 80 \%$ の値の差異がある。变位は約 2 割実

注 2) 下表に奏験の単位ラチスドームに関して, 部材を一本の連続した梁 に置換し太場合の $A_{e}, I_{e}, \lambda_{e}$ ，連続体シェルに置換した場合の $t_{e}$, $E_{\rho}$ ○計算結果を示吉。理論式は付録 1) に上る。

\begin{tabular}{c|c:c:c|c:c}
\hline Code & $\begin{array}{c}A_{e} \\
\left(\mathrm{~cm}^{2}\right)\end{array}$ & $\begin{array}{c}I_{e} \\
\left(\mathrm{~cm}^{4}\right)\end{array}$ & $\lambda_{e}$ & $\begin{array}{c}t_{e} \\
(\mathrm{~cm})\end{array}$ & $\begin{array}{c}E_{e} \\
(\mathrm{tfcm})\end{array}$ \\
\hline $\mathrm{U} 1$ & 6.33 & 33.36 & 87.13 & 7.95 & 3.22 \\
$\mathrm{U} 2$ & 6.33 & 33.36 & 87.13 & 7.95 & 3.22 \\
$\mathrm{U} 3$ & 6.22 & 31.38 & 66.76 & 7.78 & 4.30 \\
$\mathrm{U} 4$ & 6.22 & 31.38 & 66.76 & 7.78 & 4.30 \\
$\mathrm{U} 5$ & 16.25 & 164.88 & 62.76 & 11.04 & 5.95 \\
$\mathrm{U} 6$ & 16.25 & 173.03 & 84.94 & 11.21 & 4.33 \\
\hline
\end{tabular}


験值が大きい。また，実験の忘力の対称性は良好である。なお，曲 げモーメントは単位ドームの頂点の節点で最大で, 材端の節点位置 は反曲してその約 1/4〜1/5 である。この曲げモーメントが反曲する 理由は, 外周部材で面外の回転が拘束されているためである。

図 4 に実験の荷重と中央部節点変位の関係示才。また，弹性 域のみを拡大して示した。図4において，各供試体は顕著な初期 寸 べりはなく,また弾性域での繰り返し載荷による残留変形もほとん ど認められない。注3)

U 1 からU 6 の供試体は，載荷の過程において，い才゙れも部材 には顕著な座屈現象が確認できなかった。また，接合部の面内外八 の急激な耐力低下によるドームの反転などは見られなかった。これ は, 実験の供試体が, 部材の細長比が小さくドームのライズが比較 的高いことによるためである。各供試体は，緩やかな幾何非線形性 を示しながら，接合部の降伏に伴い，単位ドーム全体の㴊性が減少 し最大耐力に至っている。実験後の接合部は，単位ドーム頂点の力 ラーの圧縮側接合面において圧壊が確認された。最大耐力時のライ ズは, 完全形状のライズの $64 \%$ から $26 \%$ まで減少し, 非線形性が 比較的大きい。

U6については、降伏荷重あるいは最大荷重直前からの除荷過程 で、幾何学的非線形性が顕著に確認でき、降伏荷重時の残留変位は、 ライズの $0.8 \%$ 、最大荷重時で、2.5\%で血った。また、最大荷重付 近で、ドーム外周の引張材に㧊いてエンドプラグレストラットの溶 接部で引張破断が確認された。前述の線材による線形計算では，実 験の最大荷重 4.6tf の軸力は周辺材, 稜線材ともにほぼ $7.9 \mathrm{tf}$ であ る。つまり、単位ドームの周辺部材の引張軸力と稜線部材の圧縮力 はほほ同じ值となる。3 章で述べる弾塑性解析からも同様の結果が 得られており、ドーム頂点の鉛直変位が $10 \mathrm{~cm}$ 程度の時の周辺・稜 線部材の軸力は、約 14.3tf となっている。本実験で用いた A6061-T6 合金は溶接により耐力が溶接前の1/2 程度となる ${ }^{3}{ }^{3}$ )。(反反素材試 験結果の值の $1 / 2$ を溶接部の耐力とすれば、理論值は降伏軸力 $N_{y w}$ が $N_{y w}=1 / 2\left(\sigma_{y} A\right)=23.15 \mathrm{tf}$, 破 断 軸 力 $N_{t a r}$ は $N_{u w}=1 / 2\left(\sigma_{u} A\right)=25.68 \mathrm{tf}$ となり,ドーム周辺部材の溶接部の引張破 断は、実験の荷重・変形レベルでは生じないであろう事が予想され る。従って、この溶接部の破断は、施工過程での不具合と考えられ るが、更に実験数を增やして再現性の有無者検討打必要があろう。

図 5 にストラット材の軸力 $N$ と曲げモーメントMの関係在荷 重とともに示す。縦軸は, 計測した 2 本のストラットの平均軸力を 降伏軸力, $N_{y}\left({ }_{s} A \cdot \sigma_{y}\right)$ で無次元化している。横軸は, 計測した 2 本のストラットの 6 点の各曲げモーメントから，2本のストラッ ト材を連続した梁と見なした場合の単位ドーム頂点位置の曲げモ 一メントを求め，それをストラット軸部の降伏曲げモーメント ${ }_{s} M_{y}\left(Z_{p} \cdot \sigma_{y}\right)$ で無次元化している。図中にストラット軸部の 降伏関数 $f=\left(N /{ }_{s} N_{y}\right)^{2}+\left(M /{ }_{s} M_{y}\right)=1$ t示した。ここで, ${ }_{s} N_{y}$ と ${ }_{s} M_{y}$ の計算に用いた降伏灾力度 $\sigma_{y}$ は，それぞれの素材試験による 值を用いている。次に，接合部に関して， $M_{y}$ については文献[1]

注 3 ) 載荷試験は; 荷重・変形曲線が線形の範囲では荷重增分で、線形さ 外れた後は変位增分で行なった。しかし，オイルジャッキの加カコント ロールがプロダラム制御ではなく，任意の変位計かるいはすず多ら゙ージ をモニターすることによる手舫であるため，特に線形を外れた後は荷重 または変位が行き過ぎたりースがある。

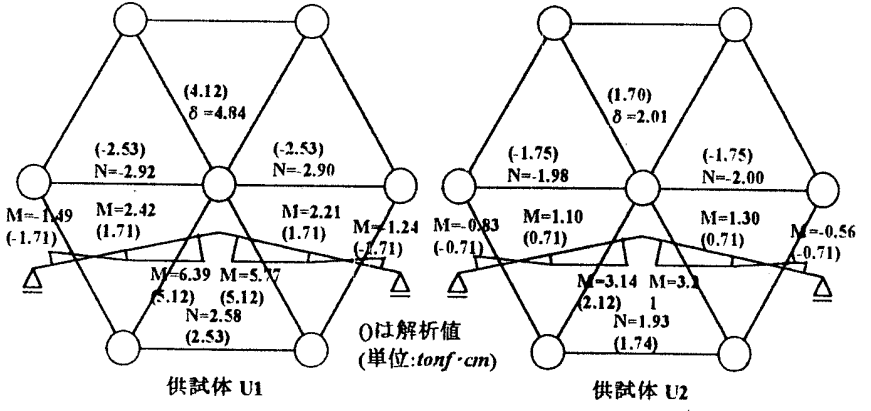

図 3. 弾性域の応力, 変形状態

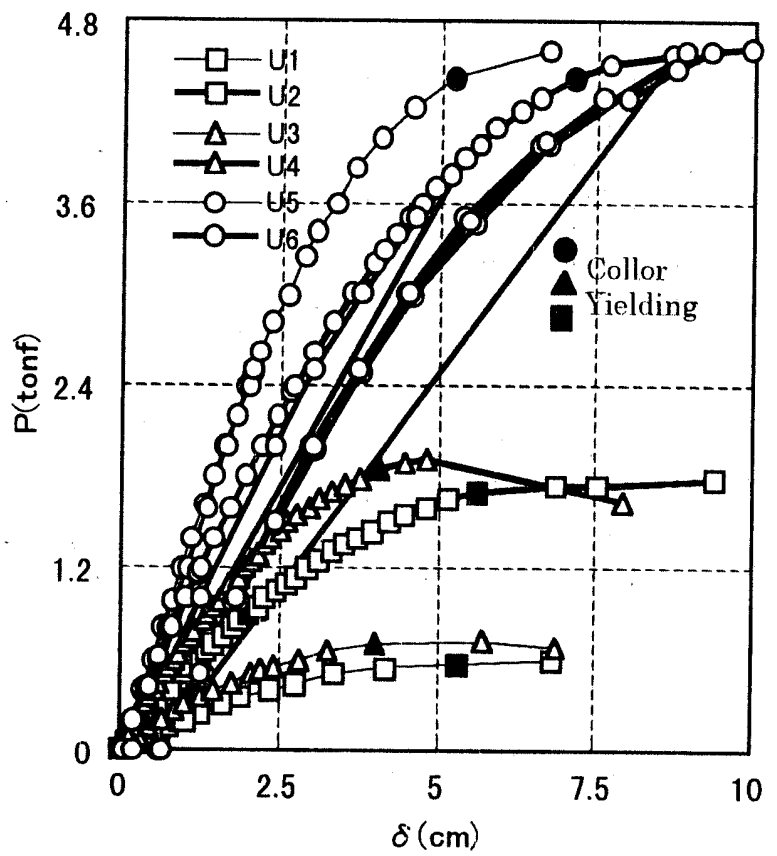

荷重·変形関係

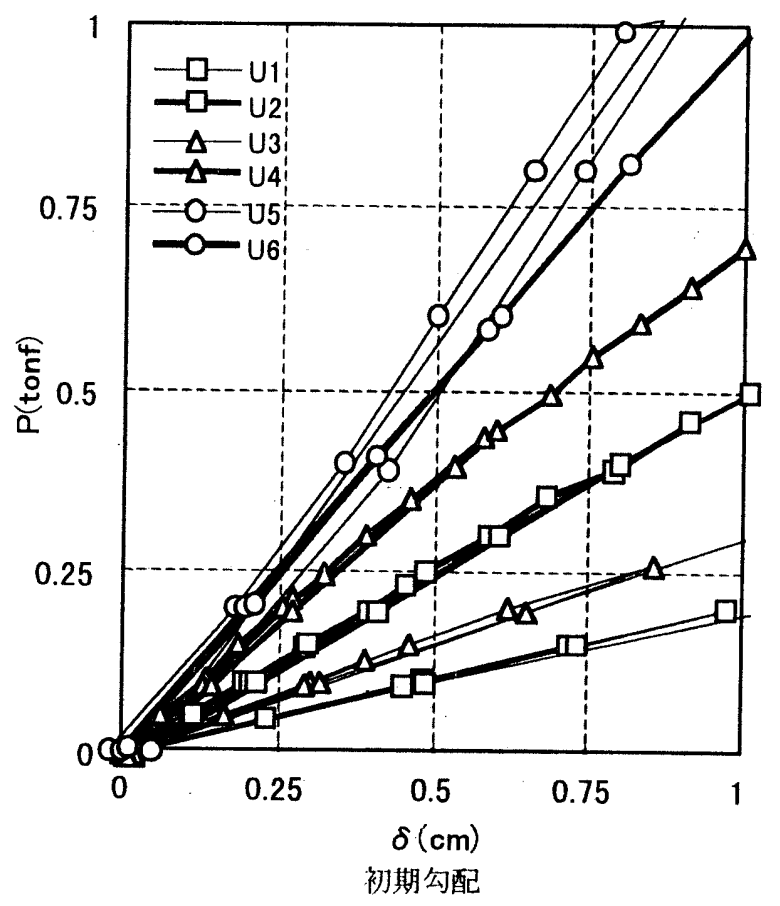

図 4. 荷重·変形関係及び初期勾配 
で得られた実験による接合部の降伏曲げモーメント $M_{y}$ 在（以降 ${ }_{c} M_{y}$ と表示する)， $N_{y}$ は同じく文献[1]で害験結果から分析された カラーの圧縮側有効断面積 ${ }_{c} A_{e}$ 老用い, $N_{y}={ }_{c} A_{e} \cdot \sigma_{y}$ として新たに 降伏関数在定義した。これ在ストラット軸部の降伏関数で規淮化し， 接合部の降伏関数 $f^{\prime}=C_{n}\left(N / s N_{y}\right)^{2}+C_{m}(M / s M y)$, 但し $C_{n}={ }_{c} N_{y}{ }_{s} N_{y}$, $C_{m}={ }_{c} M_{y} / M_{y}$ ，として図中に示した。なお，部材軸力と曲げニE一 メントの計算は，ヤング案充一定 $\left(700 \mathrm{tf} / \mathrm{cm}^{2}\right)$ としていることから 降伏関数近傍では応力在渦大に評価寸ることになる。U2の最大荷 重時の軸力と曲げモーメントはストラット軸部の降伏関数方超え ており，そのため $N-M$ 線図のプロットはストラット軸部の降伏関 数までとしている。

実験結果の単位ドームの举動は, 部材半開角 $\theta_{0}$ の影響が支配的 であり，細長比 $\lambda_{s}$ に関しては明確な違いが確認されなかった。つ まり，ストラットには部材座屁が確認されず，また細長比が変わる ことによる接合部の無次元ばね定数 の違いが, 当該実験パラメー 夕の範囲では, 接合部の降伏举動に明確な影響を及ぼしていない。 以下に, 部材半開角 $\theta_{0}$ の違いによる単位ドームの举動を比較する。

図 4 の荷重一変形曲線において, U $1\left(\theta_{0}=3^{\circ}\right)$ とU2 $\left(\theta_{0}=5^{\circ}\right)$ を比較すると, U 2 はU 1 に対して単位ドームの初期剛性が 2.3 倍 に, 最大耐力は 3 倍となっている。U $3\left(\theta_{0}=3^{\circ}\right)$ と U $4\left(\theta_{0}=5^{\circ}\right)$ では，初期剛性は 2.5 倍，最大耐力は 2.6 倍である(表 5 に一覧在 示寸)。線形剛性に関して，節点が㓮接合の場合の理論值は， $\theta_{0}=5^{\circ}$ は $\theta_{0}=3^{\circ}$ に対して 2.07 倍となる。一方, 節点がピン接合の 場合, 線形剛性は $\theta_{0}{ }^{3}$ に比例寸るた内 4.6 倍 $\left(5^{3} / 3^{3}\right)$ となる。注4）寒 験の単位ドームは節点にある程度の曲げ剛性が存在寸るた方，郕接 合の場合の理論値にほぼ符合した結果となっている。

図 5 において, 軸力と曲げモーメントの単純比率によろ曲げモ 一メントの負担率在比較すると， $\theta_{0}=3^{\circ}$ は $5^{\circ}$ に対して約 $10 \%$ 多い。 ドームの幾何非線形性は， $\theta_{0}=3^{\circ}(\mathrm{U} 1, \mathrm{U} 3)$ では, 接合部の降伏関数 の手前から現れ，ストラットの軸部の降伏関数に対寸万比が 0.2 か ら 0.6 と比較的低い応力レベルから確認できる。また, 接合部の降 伏関数をわずかに超えて最大荷重去示している。 $\theta_{0}=5^{\circ}(\mathrm{U} 2, \mathrm{U} 4)$ て は同様に 0.6 付近から生じるが，それ程明瞭ではない。また，最大 荷重は接合部の降伏関数索大きく超えてストラット軸部の降伏関 数まで達している。

U1〜U4 供試体のドーム頂点周辺のカラー周面で測定されたひ オ゙みを図 6 にプロットした。カラー上面 $\mathrm{S} 1$ での圧縮ひずタは, 部 材半開角の違いによりその進展に明らかな差異が確認された。 $\theta_{0}=3^{\circ}$ のU 1 とU 3 は, $\theta_{0}=5^{\circ}$ のU 2 とU 4 の約 2 倍の勾配で增 加している。 $\theta_{0}=3^{\circ}$ のS 1 ひずみは, U 1 で $0.56 \mathrm{tf}, \mathrm{U} 3$ では 0.70 If の荷重レ心゙ルから大きく增加している。また， $\theta_{0}=5^{\circ}$ のU2 1.70 tf, U 4 では 1.85 tf から值の增加が顕著になる。（同図の知印 参照）それぞれの荷重でのカラーのひずみは，必ずしも $0.2 \%$ 永 久ひずみを与えるものではないが，この初期降伏を接合部の線形の 荷重限界とし接合部の降伏荷重と仮定寸る。次に，カラー中立軸 注 4 ）ピン接合周辺ローラー支持単位ドームの頂部に作用する茼重 $P$ と鉛 直変位 $\delta$ ゆ釣り合い関倸は下式で表される。29)

$P=3 E A \theta_{0}^{3}\left\{(\delta / H)-3 / 2 \cdot(\delta / H)^{2}+1 / 2 \cdot(\delta / H)^{3}\right\}$ ここで, $-3 / 2 \cdot(\delta / H)^{2}+1 / 2 \cdot(\delta / H)^{3}$ が無視でき得るものと寸れば，鈖直 変位 $\delta$ は $\theta_{0}^{3}$ に比例寸る。
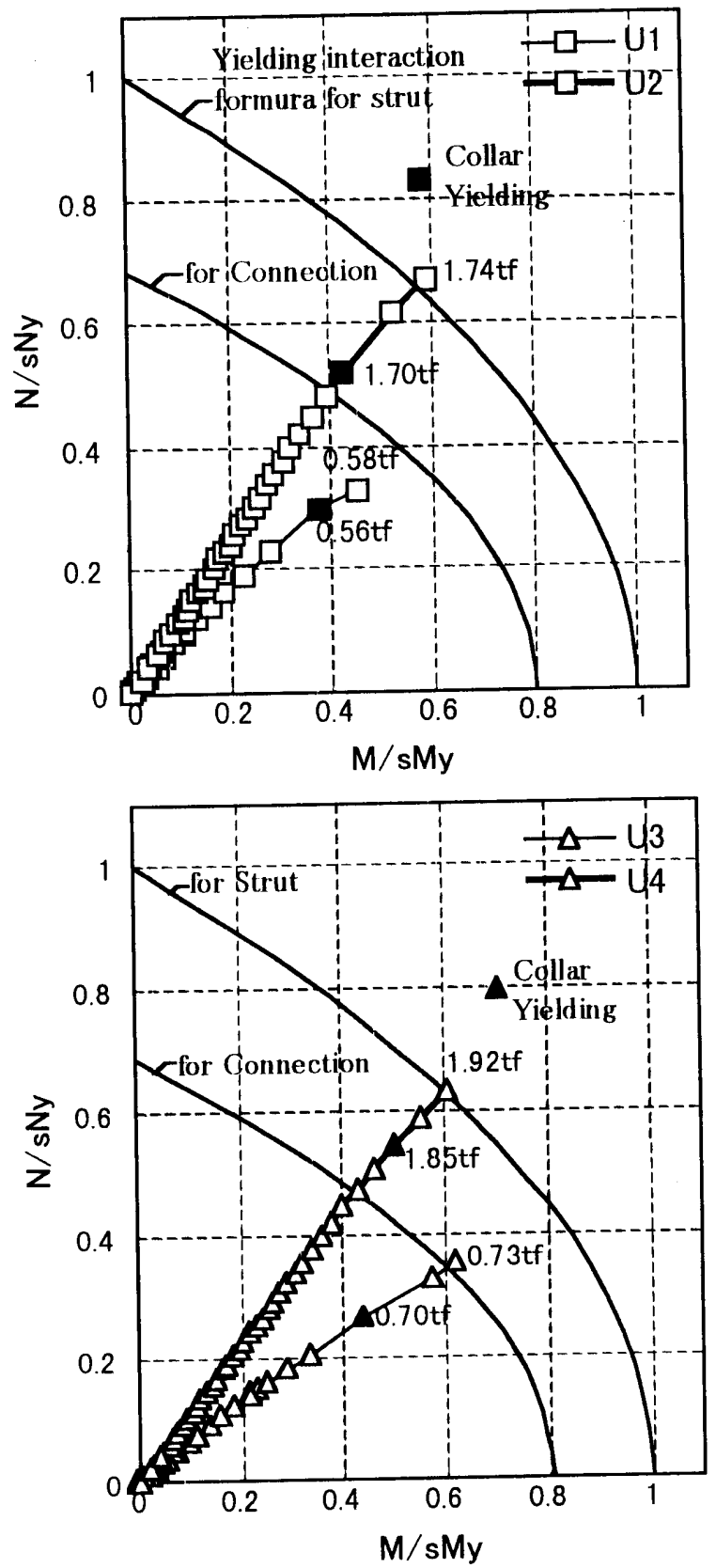

図 5.軸力と曲げ曲げモーメントの関係

のS 2 とS 4 のひずタは，U 1 からU 4 供試体いずれもS 1 の約 1/5の勾配で圧縮ひずタが増加している。最大ひずタは1000 以内である。カラー下面S 3 については，U１加U4いずれも 引張りひず马となっており，ひずみの增加傾向は中立軸の圧縮ひ

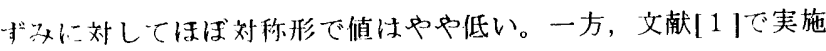
した純曲げ時の同様な分析では，カラー上面は本実験站果上同様

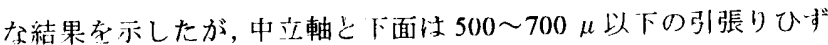
みしなっている。これは，单位ドームによる載荷試験が，軸力が 導入されることによりカラーの中立軸にも圧縮力が働くこと，ま た，い执の場合もカラーの下面は雃間して，施工時の導入軸力 が解放されること长示している。このことから軸力が存在子万実 際の忠力状態では, 文献[1]で求妉たカラーの圧縮有效断面積 ${ }_{\mathrm{c}} A_{e}$ は增加打る傾向にあると予想される。 
図 4 の荷重・変形曲線と図 5 の軸力と曲げモーメントの関倸に, 図 6 のカラーのひずみから仮定した降伏荷重を図示した。図4 に㧍 いて, この降伏茼重は, $\theta_{0}=3^{\circ}$ のU1 とU3については, ほぼその 最大荷重となっている。 $\theta_{0}=5^{\circ}$ の U2 と U4 では, それぞれの曲線 を Bi-linear とした場合，その二次勾配の線上にある。また，図５に おいてこの降伏荷重は， $\theta_{0}=3^{\circ}$ では接合部の降伏関数の手前にあ り,一方 $\theta_{0}=5^{\circ}$ では, 接合部の降伏関数とストラット軸部の降伏 関数の間にある。つまり，ドーム頂点の節点はカラーの圧縮側が軸

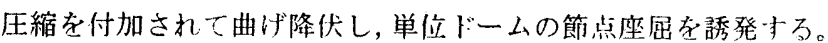
$\theta_{0}=5^{\circ}$ の降伏荷重が接合部の降伏関数圭上回っているのは, 軸力 が比較的卓越していることにより，カラーの圧縮側有効断面積、A が增加傾向にあるためと考えられる。一方， $\theta_{0}=3^{\circ}$ の場合が接合 部の降伏関数索下回っているのは， $\theta_{0}=3^{\circ}$ は形状の非線形性が大 きいことにより曲げモーメントが卓越し，またこの有効断面積，A が，荷重の增加とともに減少傾向にあるた的と推定される。

当該実験ケースからは，接合部の降伏は本節で定義した接合部 の降伏関数に， $\theta_{0}=3^{\circ}$ については 0.65 から $0.85, \theta_{0}=5^{\circ}$ は 1.1 か ら 1.3 在係数として用いることが妥当と考えられる。

\section{表 5 .実験結果一覧}

\begin{tabular}{|c|c|c|c|c|}
\hline Code & $\begin{array}{c}\text { Initial Stiffness } \\
(\mathrm{t} \mathrm{f} / \mathrm{cm}) \\
\end{array}$ & $\begin{array}{c}\text { Collar Yielding } \\
\text { Load(t) } \\
\end{array}$ & $\begin{array}{l}\text { Maximum- } \\
\operatorname{Load}(\mathbf{t}) \\
\end{array}$ & $\begin{array}{c}\text { Maximum- } \\
\text { deflection }(\mathrm{mm}) \\
\end{array}$ \\
\hline U1 & 0.20 & 0.56 & 0.58 & $68.3(0.65)$ \\
\hline $\mathrm{U} 2$ & 0.49 & 1.70 & 1.80 & $94.1(0.55)$ \\
\hline $\mathrm{U} 3$ & 0.29 & 0.70 & 0.73 & $57.3(0.74)$ \\
\hline U4 & 0.70 & 1.85 & 1.92 & $48.4(0.36)$ \\
\hline U5 & 1.24 & 4.42 & 4.60 & $67.5(0.38)$ \\
\hline U6 & 0.98 & 4.43 & 4.60 & $93.0(0.39)$ \\
\hline
\end{tabular}

注）最大変形の（）内はライズに詨する比を示要

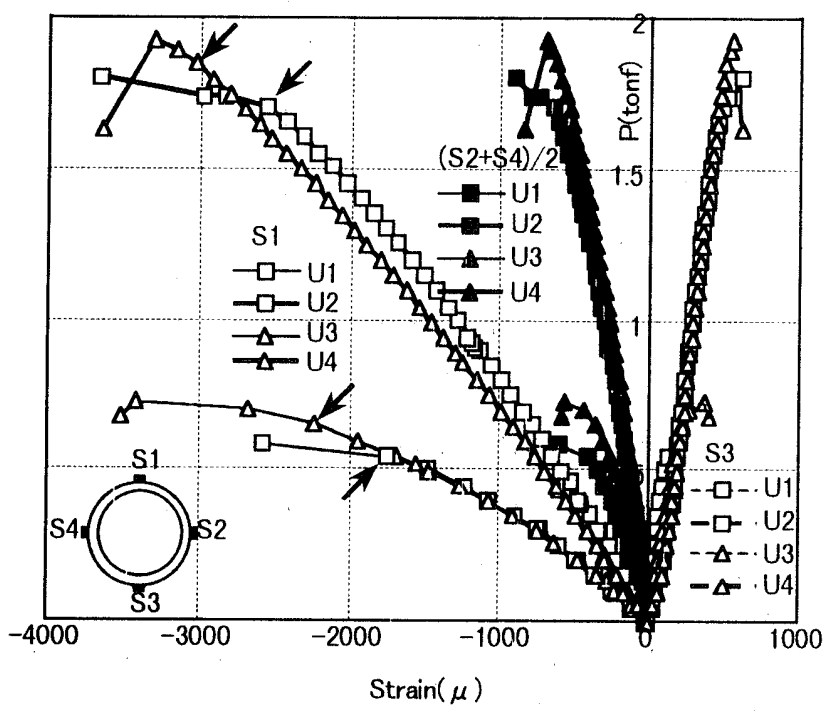

図 6.カラーの压縮ひずみ

\section{3. 数值解析}

本章では，各々の実験ケースに対して，文献[1]で採用した数值 解析法を用いて, 荷重・変形曲線を追跡した結果について述べる。

3. 1 接合部の解析モデル

接合部の解析モデルは，文献[1]で寸でに紹介しているた及，こ こでは概略の説明にとどらる。接合部は，構造物の節点となるボ 一ルに, 部材となるストラット臹製のボルトで取り时ける形式の
もので，ボルトの外側に円筒状のカラーが付されている（第2.1節 参照）。二れを図てのようにモデル化し，ボルトの忘力・ひずみ関 係任图 8 に示寸，妆じの緩み龙考慮した関数を，また，カラーの要 素には，同じく図8にあるように，引張応力が作用なる領域で仙芯

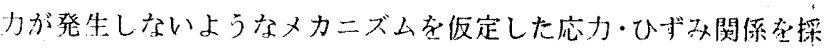

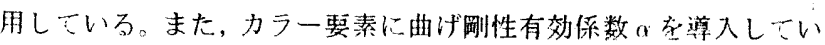
る。こ机は, 解析で用いた力ラーの断面二次モーメントを $I_{\text {。 }}$, 寒 際のカラーの断面二次モーメントを $I_{c}$ とすれば， $I_{p}=\alpha \cdot I_{c}$ 上い う関係龙仮定しての係数である。注5)

弹塑性シミュレーションは, ボルトの緩みの大きされ， $d_{r}=0.015 \mathrm{~cm}$ とし， $\alpha=0.2,0.4,0.6,0.8,1.0$ と変化させて実行され，実験で得られた 荷重・変形曲線と照查しながらその傾向と構造举動主分析した。

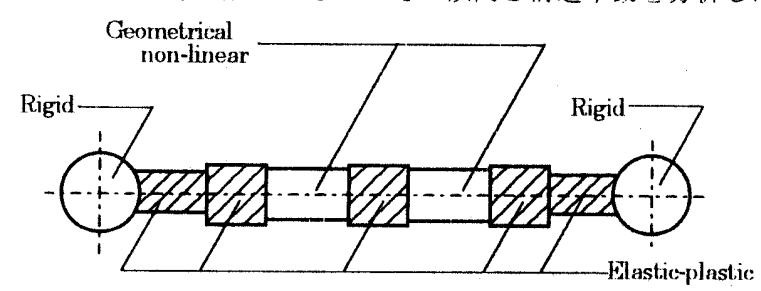

図 ‡数值解析モデル

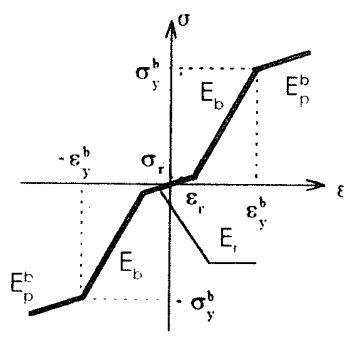

a) for bolt elements

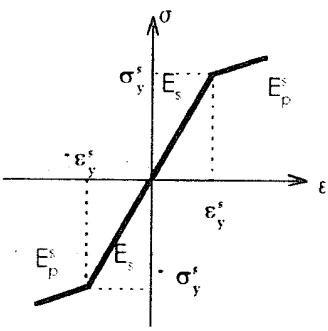

c) for strut elements

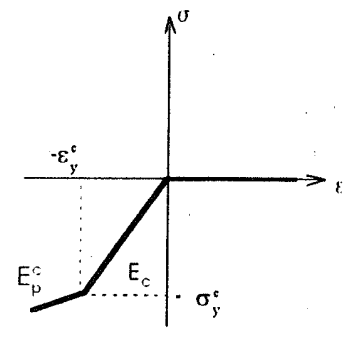

b) for collar elements

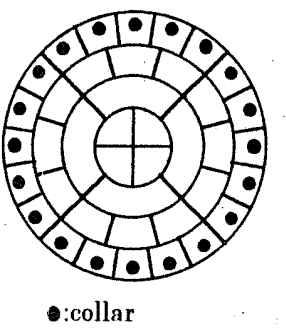

d) fiber elements at the connection section
図 8 部材の态力ーひずみ関俰

\section{2 解析結果および考察}

図 9 にU3とU6の荷重・変形曲線を示才。また，表6に荷重・ 変形曲線の初期別性 $K_{e}$, 降伏後の二次勾配 $K_{p}$, 最大荷重 $P_{c r}$ の実 験值との比較在示す。 $K$, と $K_{p}$ については, 実験子最もシミュレ 一トできるパラメータ $\alpha$ の值交示した。最大荷重はその $\alpha$ を採用し た場合の実験との差異である。

寸バてのケース龙通して，カラーの断面二次そーメントの影響を

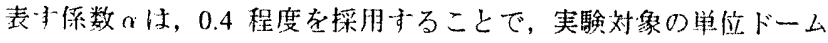
の初期唰性龙解析上に反映できることが確認できた。文献[1]の梁

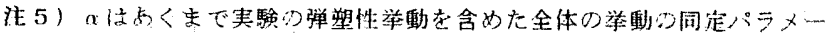

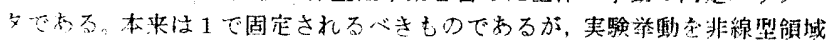

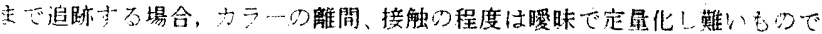

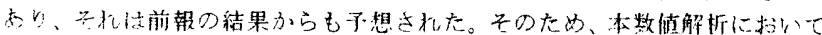

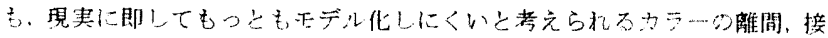

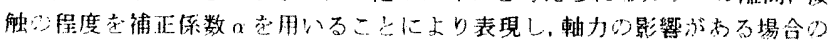
実駼学動这注跡するこししした。 

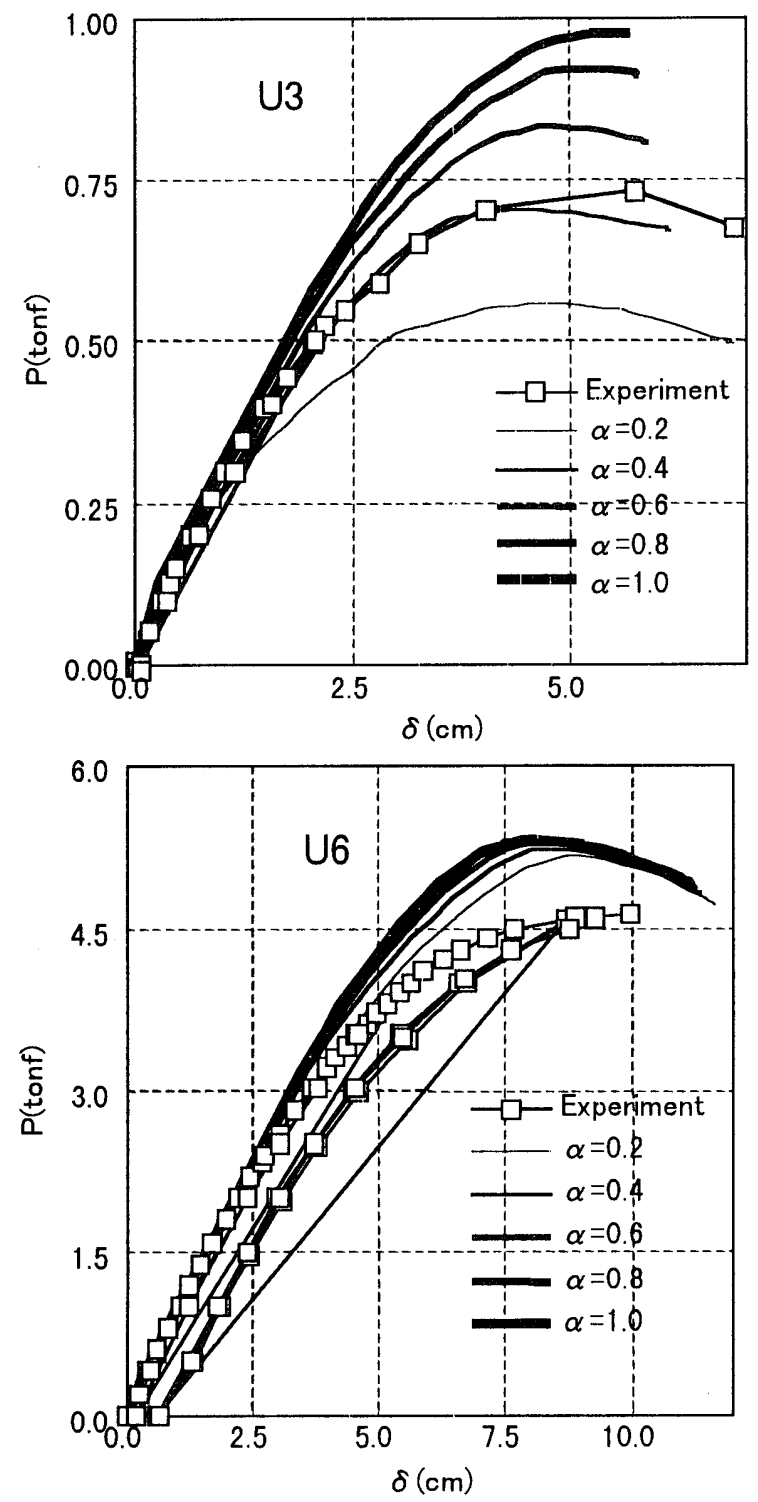

図 9 荷重·変形曲線

表6. 実験結果との比較

\begin{tabular}{|c|c|c|c|c|c|}
\hline \multicolumn{3}{|c|}{ models } & \multicolumn{2}{|c|}{ parameter-a } & \multirow{2}{*}{$\begin{array}{c}P c r \\
\text { (Ana Exper.) }\end{array}$} \\
\hline code & $\theta_{0}$ & $\lambda_{\mathrm{S}} \Lambda$ & $\mathrm{Ke}$ & $K p$ & \\
\hline U1 & $3^{\circ}$ & 1.00 & $0.6 \sim 0.8$ & 0.6 & $0.55 / 0.58=0.95$ \\
\hline $\mathrm{U} 2$ & $5^{\circ}$ & 1.00 & 0.4 & 0.2 & $1.93 / 1.80=1.07$ \\
\hline U3 & $3^{\circ}$ & 0.75 & 0.4 & 0.4 & $0.70 / 0.73=0.96$ \\
\hline U4 & $5^{\circ}$ & 0.75 & $0.2 \sim 0.4$ & 0.2 & $2.12 / 1.92=1.10$ \\
\hline U5 & $5^{\circ}$ & 0.73 & 0.2 & 1.2 & $5.5 / 4.6=1.20$ \\
\hline U6 & $5^{\circ}$ & 1.00 & 0.4 & 0.2 & $5.2 / 4.6=1.13$ \\
\hline
\end{tabular}

部材によるシミュレーションでは $\alpha$ は0.3〜0.6在採用することで赛 験举動をシミュレートできており, 本解析の結果とも符合している。 しかし，曲げの影響の出やすいむくり(部材半開角) が小さく，さ らに入/ムが 1 付近の範囲では $\alpha=0.6 \sim 0.8$ もっとも実験結果に追 従するケースもある。また，全てのケースについて弾性域では $a$ の 影響が比較的少ないが, 部材半開角が小さいモデルでは弾塑性領域 で $\alpha$ の影響が大きく現れており， $\alpha$ の取り方で単位ドームの耐力が 左右されることになる。これは 2.3 章で赛験結果主分析寸る際に
定義した接合部の降伏関数 $f^{\prime}$ が，部材半開角が小さい範围でその 耐力を汪決定していることとも傾向が符合している。しかしなが ら,カラー在含めた接合部の詳細举動の分析にはさらに細部にわた る実験し解析が必要亡されるであるう。

また，解析と実験閐に最大荷重の隔たりが 1 割程度生ずる場合 が多かったが，これは，解析がドームの頂点につながる6本の部材 が同時に同じ過程で塑性化して行くのに対して，実験では，1本の 部材が集中的に破壊して最大荷重に達していることに起因してい ると考㝋られる。

\section{4.まとめ}

本研究では，数じ込夕式ボールジョイント老用いた単位単層ラ チスドームの載荷試験と数值解析在通して，その剛性上耐力および 崩壊举動存確認した。以下に本研究で得られた結論虐要約寸る。

（1）構造実験に揖いて，実験対象の単位ラチスドームは，いづれ

も接合部が曲げ降伏し塑性化していく過程で最大附力在示し

た。部材半開角 $\theta_{0}=3^{\circ}$ の詿験体では接合部の降伏, $\theta_{0}=5^{\circ}$ で はストラットの部材座屈在想定した形状ではあったが，当硋実 験対象が，支持点の境界条件在ローラー支持さした単位ドーム であることによる曲げ挙動の卓越と、接合部の举動との複合に より、実举動では、接合部の曲げ降伏によって耐力に至ったと 考えられる。

(2)軸力乞曲げモーメントが導入された場合の接合部の降伏举動 は，文献[1]で得られた接合部の降伏曲げモーメントとカラーの 王縮有效断面積，A 汶対寸万降伏軸力を用いた降伏関数により ほほ表現可能でる。この降伏関数を構造設訃に用いる際の補 正係数は，本研究で対象しした，部材細長比が約 $60 \sim 80$, 接合 部の無次元ば敉定数が約 2 5 の範囲では, 部材半開角 $\theta_{0}=5^{\circ}$ については約 $1.2, \theta_{0}=3^{\circ}$ では約 0.7 が妥当であうう。なお， 部材細長比と無次元ば称定数が大きく異なる場合について，さ らに詳細な分析が必要と考えられる。

(3) 実験結果の単位ドームの举動は, 部材半開角 $\theta_{0}$ の影響が支 配的であり，接合部で降伏したことも克り，細辰比入に関して は明確な違いが確認されなかった。実験刘象の $\theta_{0}=5^{\circ}$ は $\theta_{0}=3^{\circ}$ に対して，その剈性と耐力が約 2.5 倍から 3 倍に上昇し た。丰沈态力の非線形性は， $\theta_{0}=5^{\circ}$ はストラット材の降伏関数 までほぼ生じていないが， $\theta_{0}=3^{\circ}$ は接合部の降伏関数付近か ら生じた。すなわち， $\theta_{0}$ が小さい場合は，実用的な設計レ心゙ ルでも幾何非線形在考慮した分析が必要であるう。

（4）数值解析において, カラーの曲げ用性有効倸数 $\alpha$ 龙導入し, 実験対象の単位ドームの荷重一変形履歴を追跡した結果， $\alpha$ $=0.4$ 程度の值在取ることで、挙動の追跡ができるであるうと思 われる結果となっている。この $\alpha$ の值は文献[1]で実施した単純 梁による同様な数値解析結果の $\alpha=0.3 \sim 0.6$ とも符合している。 しかし，弾塑性域まで丁寧に追跡寸るには 0.2 0.8 までの值も 取り得り、実験サンプル数を増やすことで、精度在上げていく 必要があろう。

今後は，本砰究で得られた接合部の特性孝用い，実規慔の単層ラ チスドームの静的执よび動的座屈解析から，当該接合部交用いた単 層ラチスドームの座屈耐力と崩壊举動の分析を進的る予定である。 


\section{謝辟}

本研究を進めるにあたり，包括的なご教示をいただきました豊橋 技術科学大学教授・加藤史郎博士，構造実験に関してご指導いただ きました住友軽金属工業の山口進吾氏，実験に多大なご協力たいた だきました同・技術㸴究所の水越秀雄氏に染く感謝いたします。

\section{参考文献}

1）桧山裕二郎，高島英幸，飯島俊比古:アルミ合金単層ラチスドームに用 いるボールジョイントの載荷実験及び弹塑性解析, 日本建等学会搆造系諭 文集，第 502 号，pp85 92，1997. 12

2）坂毒二, 日置興一郎: 私じ込子接合で組み立てた立体卜ラスの座屈举動， 日本建築学会論文報告集，第 331 号，pp. 1 9, 昭和 58 年 9 月

3）岩田衛，和田章，白井貴志：太径ポルトを用いたシステムトラスの佊労 試験，日本建筑学会構造系論文報告集 (報告)，pp. 123 134，1991.4

4) 谷口与史也, 坂蔓二：双じ込み接合システムトラスの実験的破究，日本 建築学会槽造系論文報告集, No. 408, pp. 91 99，1995.2

5 ) 辻岡静夫, 山田義智, 安井信行, 今井克彦, 䏦山広三: 立体卜ラス接合 部の疲労特性に関する実験的研究，日本建築学会構造系袷文報告集， No. 490, pp. $223 \sim 228, \quad 1996.12$

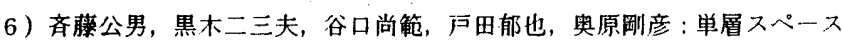
フレーム'(EXP0'85 南グートドーム) の載抲奏験, 日本建筑学会大会学 術講演梗概集（北海道）， pp. 281 282，1986.8

7) 植木隆司, 向山洋一, 生村昌明, 加藤史郎：巣層ラチスドームの載荷試 験および弹塑性座屈解析, 日本建築学会槽造系論文報告集, 第 421 号, pp. $117 \sim 128,1991.3$

8）植木隆司，松栄泰男，加藤史郎，山田㕵志: 単位单層ラチスドームの載 荷試験书よび弾塑性座屈荷重，日本建策学会楎造系論文報告集，第 452 号, pp. 67 76, 1993. 10

9）鈴木敏郎，小河利行，久保寺勲，五十嵐規矩夫，ボー儿接合単層ラチス ドームの座屈実験及び弾塑性座屈解析一中央集中荷重を受け万部分球形ド 一ムについて-, 日本建築学会檴造系論文報告集, 第 444 号, pp 53 3 62, 1993.2

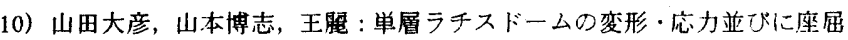
特性に対する接合部㓮性乙荷重条件の影響に関寸万研究-その 1 . 変形・态 力伝達特性について, 日本建築学大会学術講演梗概集, 関東, pp142i 1428, 昭和 63 年 10 月

11）山田大彦，山本博志，王麗：単層ラチスドームの変形・応力並ずに座屈 特性に対する接合部用性と荷重条件の影響に関する研究一その2. 座屈耐 力について, 日本建筑学大会学術講演梗概集, 関東, pp1429 1430, 昭和 63 年 10 月

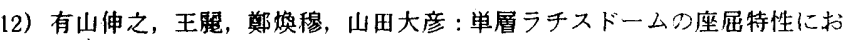
ける接合部回転用性と荷重条件の影響に関する研究, 日本建筮学大会学術 碡演梗概集，九州，pp1245 1246，1989.10

13）植木隆司，加藤史郎，向山洋一，松栄泰男：雨端に回転ば和のある部材 で構成される単層ラチスドームの弾塑性座屈抲重, 日本建筑学会權造系 踚文報告集，第 448 号，pp. $47 \sim 58 ， 1993.6$

14) YAMADA, M. , UCHIYAMA, K., YAMADA, S., ISHIKAWA, T. : Theoretical and Experimental study on the Buckling of Rigidly Jointerl Single Laver Latticed Spherical Shells under External Pressure, IASs Symposiun, OSAKA, 1986, Vol. 3

15）植木隆司，向山洋一; 加藤史郎：両端に回転ば权のある部材で構成され る単層ラチスドームの線形抢よび弾性座屈荷重一矩形平面形状をして裁断 球設状ドームについて一, 日本建築学会構造系踰文報告集, 第 441 号, pp11て $\sim 129,1990.5$

16）加藤史郎，山田聖志，高自英幸，柴田良一：㓮接合単層ラチスド一ムの 座屈応力度に関する研究，日本建策学会構造系論文報告集，第 428 号。 pp. $97 \sim 105,1991.10$

17）加藤史郎, 柴田良一，㨁木隆司：用接合単層ラチスドームの座屈荷重推 定法〜部材の座屈応力度用いる方法〜，日本建築学会構造系論文報告 集，第 436 号， pp. 91 103，1992.6

18) 加藤史郎, 生村昌明 : 接合部の曲げ用性が円形平面状の単層ラチスドー ムの座屈荷重に与える影響〜部材の座屈応力度曲線の表現について〜。

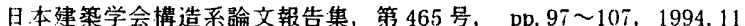

19）柴田良一，加藤史郎，植木隆司：きすめて偏平名剛接合单首ラチスドー 厶刀弹塑性座屈荷重〜等分布荷重を受ける周辺ピン支持 6 角形平面ドー

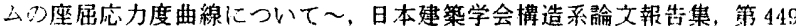

号, pp. 143 153, 1993.7

20) Fujimoto, M., Imai, K. and Saka, T. :Buckling of Single Layer Lat ticerl Dome under Uniform Gravity Load, SPATIAL, LATTICE, and TENSION STRUCTURE, Proceerlings of the IASS-ASCE International Symposium, Atlanta, pp. 509 518, 1994.4

21) Ohsawa, K. and Yamada, M. : Estimation of U1timate Structure of Rigidly Jointed Single-Layer Latticed Domes Subjected to Distributed Load, IASS, Beijing, pp. 366 373, 1996. 5

22）半谷裕彦，小田畫史，西田明美: 单層ラチスシェルの飛移座屈と接合部 㹉れ座屈の相関その1〜現象之解析モデル〜，日本建築学会学術講演梗

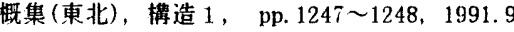

23) 半谷裕彦, 小田㶳史，西田明美：单首ラチスシェルの飛移座尼と接合部

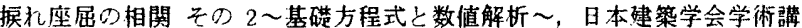
演梗摡集 (東北)，槽造 1，pp. 1249 1250，1991. 9

24）高岛英幸, 枈田良一，加藤史郎：スペースフレーム接合部门数值シミュ レ…ション法, 日本建筑学会構造系論文報告集, 第 455 号, pp. 10.5 111, 1994.

25）高岛英幸，加藤史郎：緩みのかる接合特性を有する単層ラチスドームの

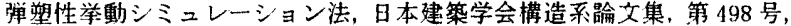
pp $91 \sim 97,1997.8$

26）杉崎健一, 河村繁，半谷裕彦：アルミニウム单層卜ラスの博造举動に関 する実験的研究，日本建策学会溝造系論文集，第 480 号, pp. 113 122. 1996. 2

27）杉畸健一，河村繁，半谷裕彦：はめあい接合部を有するアルミニウム单 層卜ラスの解析, 日本建策学会棈造系綸文集, 第 488 号, pp. $97 \sim 106$, 1996. 10

28）武藤至，生村昌明，加藤史郎：半甽接単層ラチスドームの座屈耐力の一 評洒法について, 日本建築学大会学術講演梗摡集, 関東, pp1341 1342, 1993. 9

29）日本建築学会: 単層ラチスドームの安定解析(その現状と問題点)，1989

30）日置興一郎，䯇節・ピン節理想単層ラチスドームの全体座屈・個材座屈・ 節点座屈の表示法について一境界条件の悪影響を受け交い場合一, 日本建築 学会大会学術講演梗概集，関東， $p p 1337 \sim 1338 ， 1993.9$

31）日本建筑学会シェ儿架間構造運営委員会：空間骨組慣造 形態・性能. 生産, 日本建策学会, 1995.12

32) Douglas T. Wright: Membrane Forces and Buckling in Reticulated Shells, ASCE, 1965.2

33）建設省建策研究所：アルミニウム合金利用技術指針，1996.12

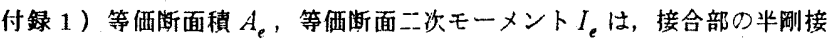
合的乲特性を考虑し，次式により算出している。29，

$$
\begin{aligned}
& A_{s}=A_{p} / \gamma_{2}, \gamma_{2}=\left\{1-2 \lambda_{1}-2 \lambda_{2}\right\}+2 \lambda_{2} E_{p} A_{p} / E_{s} A_{s} \\
& I_{c}=I_{p} / \gamma_{1}, \gamma_{1}=\left\{1-2 \lambda_{1}-2 \lambda_{2}\right\}+2 \lambda_{2} E_{p} I_{p} / E_{s} I_{s}
\end{aligned}
$$

こニで，EAはカラーのみの軸㓮性を， $E_{s} I_{s}$ は夷験で求めた接合部の曲げ

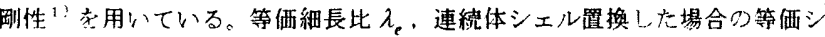
エル厚 $t_{e}$ ，等価ヤング原数 $E_{e}$ は，それぞれ次式により計算される。

$$
\left.\lambda=\frac{l}{r_{e}}, \quad \text { (但 } ᄂ, r_{e}=\sqrt{\frac{I_{e}}{A,}}\right), t_{e}=2 \sqrt{3} \cdot r_{e}, \quad E_{e}=\frac{E A_{e}}{3 r_{e}}
$$

(1998年 5 月20日原稿受理，1998年11月 9 日採用決定） 